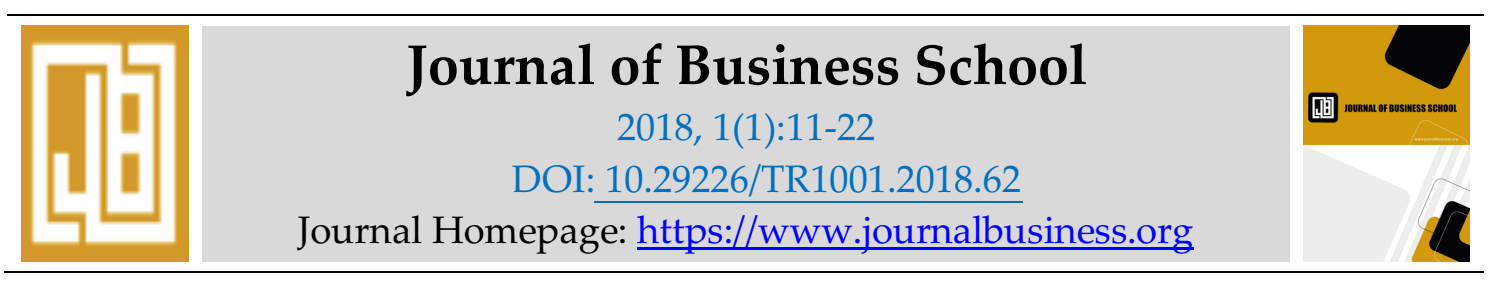

\title{
Determinant Factors of Remittances in Albania
}

\author{
Elfrida Taraku \\ Finance - Accounting department, Business Faculty University "Aleksandër Moisiu" of Durrës, \\ Durrës, Albania, itaraku@yahoo.com \\ Ejona Duçi \\ Finance - Accounting department, Business Faculty University "Aleksandër Moisiu" of Durrës, \\ Durrës, Albania, jonaduci@yahoo.com
}

\begin{abstract}
Over the years, remittances have attracted the attention of researchers, policy-makers, civil society representatives and the international community due to the variation of their flows each year and more. The main purpose of this paper is to reflect some of the main macroeconomic and macroeconomic remittances in developing countries. In the case of Albania, the paper aims to present the impacts of income from remittances with well-being and the decisions of Albanians regarding the use of these revenues. In this paper we will elaborate in detail the factors that determine the remittances of Albanian emigrants. The model that results best in showing the link between remittances and their determining factors is the linear dummy independent model. The source of information is the World Economic Outlook. Data on remittances are obtained from the Balance of Payments of the Bank of Albania and include the monetary transfers of emigrants who are employed in the host country and are considered resident in this country's economy

The data are in time series and I have seen the impact of these factors on the performance of the years, respectively for the last 30 years. And we have come to the conclusion that the GDP factor is the factor that has the greatest impact on the remittances of Albanian emigrants. Unlike other economic issues, on the issue of remittances in Albania the studies undertaken are scarce, and the study of this field is a innovation for our country. The results of the work indicate that remittances are an important item of the Balance of Payments that affects the macroeconomic stability of the beneficiary country and also contributes to increasing household consumption, reducing poverty and improving the level of living.
\end{abstract}

Keywords: unemployment, GDP, emigration, developing countries, remittances, consumption, income, balance of payments. 


\section{Introduction}

In 1989, Aristide Zolberg, a renowned international migration researcher, wrote that if all the world's countries were comprised of Albania on one side and Japan on the other hand, it would not be necessary to study international migration. Almost a year later, ironically, a massive wave of international migration, often illegal and chaotic, would make Albania one of the world's most affected countries by this phenomenon. As Russell King calls it "a kind of laboratory for studying new migration processes". This phenomenon, present throughout the country's territory, has accompanied with different intensity all stages of Albanian transition. Almost 12 years after the start of the transition, about $1 / 5$ of Albanians or over 600,000 people, mostly young people, have migrated abroad, especially in Greece and Italy. While internal migration has included hundreds of thousands more. One of the most important aspects of this phenomenon, which has a great economic and social impact, is remittances. Remittances are an important source of income for households, especially for developing-country families. Ever since the labor market was internationalized and became part of the globalization process as many other markets, and people could move freely from one place to another to work, the importance and attention paid to remittances has been growing ever. What is to be noted is that the growth rate of remittances has been stable even during the crisis years compared to foreign direct investment.

Referring to the most recent official data, it was estimated that about 1.2 million Albanians lived in emigration in 2008, accounting for a significant part of the Albanian population (about 25\%). Out of them, $85 \%$ live and work in Greece and Italy, while the rest in Western Europe and the United States.

According to official data of the Bank of Albania, remittances to Albania have increased at an average annual rate of $5.6 \%$ over the last 15 years. The last five years show a decline in remittances from 952 million euros in 2007 to half in the years 2012-2013.

\section{Metodology}

The goal of this paper is to identify the determinants of remittances of Albanian emigrants. The data used in the search are secondary and taken from the Bank of Albania, World Bank and World Economy Outlook (WEO). This data is a series of times, for 30 years. Specifically, data on GDP and Albanian population levels as well as GDP, unemployment rate, interest rate and Greek population level were obtained.

I used econometric modeling to measure the statistical relevance of the link and factor influence. The model that results best in showing the link between remittances and their determinants is the linear model with independent variables.

Official data on remittances include transfers sent via formal channels (commercial banks or money transfer agencies) and informal channels (cash at border points). Therefore, in this study it is considered that the methodology of measuring remittances together with their dynamic performance and the chaotic state of Albanian emigration may present limitations that need to be considered, as it may affect its empirical findings.

\section{Main problem}

Through this research I want to throw the first steps in clarifying this little problem beating in the case of Albania. It is known that this issue is less addressed with regard to remittance determinants. One of the reasons why I chose to study this phenomenon is that remittances constitute one of the sources of income in our country. Relying on statistics that have resulted in larger shipments have from our neighboring country Greece. Also, given that Greece is affected 
by the global economic crisis, will analyze how this phenomenon has affected shipments of emigrants.

\section{- The impact of the Greek crisis on remittances}

Greek crisis brought less revenue coming from Albanian emigrants, the deterioration of the status of migrant workers, while a number of enterprises, confection type, that have activity in southeast and southern Albania lost market in Greece.

Consequently, the production volume decreased by reducing the number of employees. During 2010, the Greek financial and economic crisis led to Albanian immigrants live and work in Greece to lose confidence in the Greek banking system.

Under this panic and insecurity, most immigrants have seen Albania as safer. The fear and the collapse of Greek banks made in our country come to EUR 514 million as remittances. The measures taken by the Greek government did not affect imports alone. They had a direct impact on Albanian emigrants working and living in Greece. The resultant is that Albanian immigrants remain less savings to send families here, and to develop a business or buy property in Albania. Below is a graph of the main countries from which we have the largest incomes. Albanian economist Adrian Civici, says it is difficult to estimate the number of returnees, because many are not fully back, they come and go. In many cases migrants return to their villages that they may have left 15 years ago to see if it is possible to find a job, or even work in agriculture. Seeing both as impossible, they return to Greece. Based on the chart and seeing that the largest income is from the Greek state I have done exactly these research subject for remittances coming from Albanian emigrants.

\section{- Variables}

The research question is: determination of key macroeconomic variables to consider as potential factors remittances.

Following the literature on macroeconomic remittance determinants, we have classified the variables that could potentially affect the behavior of remittances in three categories:

$\neg$ the variables that represent the macroeconomic situation of the country of origin;

$\neg$ the variables that represent the macroeconomic situation of the host country;

$\neg$ The variables that capture the links between the host country and the country of origin.

\section{Economic variables of the country of origin}

The economic activity of the country of origin used in many studies as a proxy to reflect the employment opportunities and generating income of immigrant families (Sayan and Tekin-Koru, 2007; El-Sakka, 2005; and Eric Lüeth and Marta- Ruiz Arranz, 2007). However, the effect of GDP on remittances depends on the remittance remittances prevailing in Albanian emigrants. If altruism is the main push, negative shocks to GDP in the country of origin will encourage immigrants to send more remittances. But if remittances are sent for investment purposes, negative shocks in the country's origin production will reflect worsening investment opportunities and consequently lead to a reduction in remittances. In this model, we choose as variables of representatives of the origin country: GDP, population and level of interest rates.

\section{The host country's economic variables}

To represent the host country we use Greece's unemployment rate. To build the index, the weights that give the unemployment rate is based on the remittances that come from this country. Previous studies show that the GDP of the host country is also an important determinant of remittances because it translates to greater labor demand, higher wages, higher incomes and consequently higher shipments. (Higgins et al., 2004). In this topic, the host country's 
representative variables are: the unemployment rate, the gross domestic product, the interest rate as well as the host country. Data for Greece are taken from World Economic Outlook.

\section{Economic variables of the host country and place of origin}

To represent the connection between the host country and country of origin, use nominal exchange rate ALL / EUR, by the Bank of Albania.

\section{- Model}

The central hypothesis of this research, which I will try to evaluate is: Remittances of Albanian emigrants are determined by the factors of the host country (Greece) and the factors of the country of origin (Albania).

Concepts and their measurement:

- Remittances are incoming transfers from outside, which constitute one of the main economic engines. It is the variable we have taken in the study in the form of a dependent variables. - Gross domestic product is the market value of all final goods and services produced in one country over a given period of time. This information I provided for 30 years by the World Economic Outlook and the data are in millions. This factors've seen in the form of the independent variable and in the context of the two countries, namely Greece and Albania

- The unemployment rate represents the percentage of unemployed from the entire capacity of the workforce in a certain area within a country or across the country. So, this economic indicator shows the level of untapped labor force in economic processes in a geographic area. This concept will bring as the independent variable, measuring it with Greece's unemployment rate. - The level of population is another factor that plays an important role in the determinants of remittances. I have taken into account the total number of population for both countries.

- The interest rate is the regular cost that the lender decides on the borrowed funds. This is usually expressed as a percentage of the loan amount, and is calculated on an annual basis. Interest rate inevitably affects the amount of the monthly installments to borrowers. In the model it is introduced in the form of an independent variable as provided for Greece.

- Dummy has been introduced to the model as an independent variable to show how the crises and the general messes of 1997 had affected. To see this effect we made a breakdown of the years, before 2000 we marked 0 and after 2000 I marked it with 1 . The model is in the form of an independent variable.

\section{- Model with all factors}

The model used to determine the Remittances factors is linear model with independent dummy. This model best expresses this connection. I inserted the variable model with independent dummy to show structural differences between the two periods, before 2000 and after 2000. I have chosen this period because of two major events, the Albanian transition in 1997-1998 and change monetary crisis that occurred in the EU countries, including Greece (the introduction of the Euro). The following model contains all the determinants of remittances.

The model is:

$\mathrm{Y}=0.0025 * \mathrm{X}+0.016 * \mathrm{Z}+2.62 * \mathrm{P}-24584456 * \mathrm{~L}+261,31 * \mathrm{M}-700,86 * \mathrm{~K}-$

$20637465 * \mathrm{I}+\mathrm{e}$

P - Dummy, L - Greek unemployment rate, M - Greek population, K - Albanian population, I Interest rate, e - Remaining terms. 
Based on the above probabilities, the model turns out to be important as well as the majority of coefficients, indicating that there is multicolinearity, to eliminate it we seek a better model.

Table 4 - Model with all variables.

\begin{tabular}{lcccc}
\hline \multicolumn{1}{c}{ Variable } & Coefficient & Std. Error & t-Statistic & Prob. \\
\hline Greek Gdp & 0.002664 & 0.000698 & 3.814317 & 0.0009 \\
Albanian Gdp & 0.016471 & 0.006906 & 2.384921 & 0.0261 \\
Dummy & $2.62 \mathrm{E}+08$ & $1.30 \mathrm{E}+08$ & 2.018886 & 0.0559 \\
Unemployment rate & -24584456 & 9164176. & -2.682670 & 0.0136 \\
Greek population & 261.3114 & 130.4865 & 2.002594 & 0.0577 \\
Alb. population & -700.8577 & 366.9467 & -1.909971 & 0.0693 \\
Interest rate_ & -20637465 & 30764432 & -0.670822 & 0.5093 \\
\hline R-squared & 0.895596 & Mean dependent var & $7.67 \mathrm{E}+08$ \\
Adjusted R-squared & 0.867123 & S.D. dependent var & $3.84 \mathrm{E}+08$ \\
S.E. of regression & $1.40 \mathrm{E}+08$ & Akaike info criterion & 10.55882 \\
Sum squared resid & $4.31 \mathrm{E}+17$ & Schwarz criterion & 40.88885 \\
Log likelihood & -581.1028 & \multicolumn{2}{c}{ F-statistic } & 31.45340 \\
Durbin-Watson stat & 2.213211 & \multicolumn{2}{c}{ Prob(F-statistic) } & 0.000000 \\
\hline
\end{tabular}

- In search of finding a better model

In trying to find a better model I have tried some models. I have tried the logarithmic model, the dummy line model, the lin-log model and the log-lin model and have been trivial. The appropriate model is linear with independent dummy model. This is because the coefficient R2 has resulted to be the highest and the lowest AIC.

Our model is:

$\mathrm{Y}=0.003 * \mathrm{X}+0.016 * \mathrm{Z}+3.18 * \mathrm{P}-24033061 * \mathrm{~L}+207.1{ }^{*} \mathrm{M}-569.1{ }^{*} \mathrm{~K}+\mathrm{e}$

Where: $Y$ - Remittances of Albanian emigrants, X - Greek GDP, Z - Albanian GDP, P - Dummy, L - Greek unemployment rate, M - Greek population, K - Albanian population, e - Remaining terms.

\begin{tabular}{lcccc}
\hline \multicolumn{1}{c}{ Variable } & Coefficient & Std. Error & t-Statistic & Prob. \\
\hline Greek Gdp & 0.002547 & 0.000668 & 3.812336 & 0.0009 \\
Albanian Gdp & 0.016516 & 0.006823 & 2.420688 & 0.0238 \\
Dummy & $3.18 \mathrm{E}+08$ & 98461866 & 3.226455 & 0.0037 \\
Unemployment rate & -24033061 & 9017449. & -2.665173 & 0.0138 \\
Greek popu & 207.1191 & 101.2394 & 2.045834 & 0.0524 \\
Alb population & -569.0991 & 306.2258 & -1.858429 & 0.0560 \\
\hline R-squared & 0.893461 & Mean dependent var & $7.67 \mathrm{E}+08$ \\
Adjusted R-squared & 0.870300 & S.D. dependent var & $3.84 \mathrm{E}+08$ \\
S.E. of regression & $1.38 \mathrm{E}+08$ & Akaike info criterion & 10.51010 \\
Sum squared resid & $4.40 \mathrm{E}+17$ & Schwarz criterion & 40.79299 \\
Log likelihood & -581.3964 & F-statistic & 38.57656 \\
Durbin-Watson stat & 2.173516 & Prob(F-statistic) & 0.000000 \\
& \multicolumn{5}{c}{} \\
\hline
\end{tabular}

\section{Results}

Testing the importance of the model is made by the Fisher test, which we mark with F. The hypotheses to be tested are: 
Basic hypothesis (Ho): The model is not important.

The alternative hypothesis (H1): The model is important.

We claim that the model is important because by comparing the value of Prob (F-statistic) with the $5 \%$ level, we will notice that $0.00 \%<5 \%$ this indicates that our model is important at very good level, as it is very less than $5 \%$. Of particular importance when discussing the quality of the model gets the determination coefficient, which expresses the extent of the variation of remittances explained by the variation of factors taken into consideration in the composite in the form of the model being considered. In our case it is 0.893461 . So, $89 \%$ of the variance of remittances is determined by the Greek GDP, Albanian GDP, Greek unemployment rate, Greek and Albanian population. While $\mathrm{R}=89.3 \%$ is very close to 1 , then we can say that there is a strong link between the addictive and the independent variables.

\section{The Test of heteros}

The Ewievs program performs White's test in two options, with and without cross-section. The test for the presence of heterosit free cross-section follows this procedure steps:

1) The hypothesis is formulated:

The hypothesis (Ho): Heterosi is not present.

The alternative hypothesis (H1): Heterosi is present.

2) To find the actual value used formula $(R 2 * n)$, where $n$ means the number of data. In our case it is 30 .

3) Appreciate the critical value of this criterion, which has $X 2$ distribution with probability $\alpha$ and with degree of freedom as the number of parameters.

4) Compared the actual Watt test value with its critical value. If $n{ }^{*} R 2>X 2$, then we say that the alternative hypothesis is accepted and rejected it based on the opposite say that the model does not suffer from heterosi.

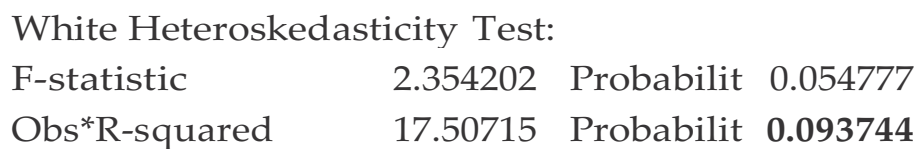

In our model we will see that the probability $0.093744>0.05$, then the basic hypothesis on the absence of heteros are not discarded, so our model does not show heteroskedasticity. We can say that this is due to a large enough number of data. 
Figure 8 Distribution of waste

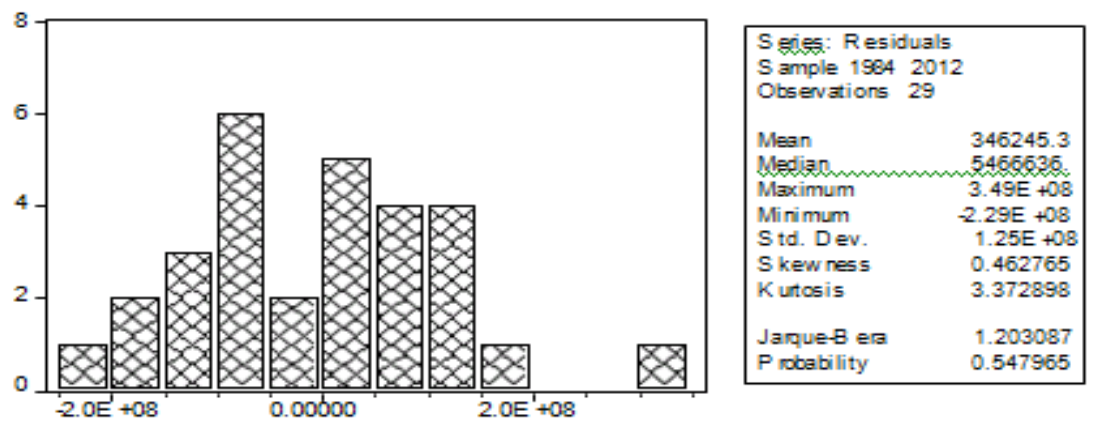

In order to verify the normal distribution of the term error, we first formulate the hypotheses:

Basic Hypothesis (Ho): The term of error is normally distributed.

Alternative hypothesis (H1): The term of error is not distributed normally.

An econometric model would be better if the error term will have normal or nearly normal distribution. To show this comes in aid criteria Jarque Bera (JB).

In our model we will see that probability $0.547965>0.05$, then the basic hypothesis about the normal distribution of the error term is not discarded, so the term of error of our model shows normal distribution

\section{The addition of variables}

Examining excess variables is assessed by the student test (test $t$ ), which we have discussed above. There are several methods to control from the statistical viewpoint the absence in the model of important variables. The test that we will use is Reset testing. The hypotheses that are tested are:

The hypothesis (H0): The model is well specified or there is no need to add other variables. The alternative hypothesis (H1): The model is not well specified or needs to add other variables.

\begin{tabular}{llll}
\multicolumn{4}{l}{ Ramsey RESET Test: } \\
\hline F-statistic & 0.592582 & Probability & 0.56188 \\
Log likelihood & 1.592138 Probability & $\mathbf{0 . 4 5 1 0 9}$ \\
\hline
\end{tabular}

From the table we arrive at the result that the probability $0.451099<0.05$, then the basic hypothesis is accepted. The model is well chosen or does not need to add other variables.

\section{Discussions}

$\checkmark$ Greek GDP: If Greek GDP will increase by one unit, while keeping all other factors constant, the Albanian remittances will increase by 0.002547 units.

$\checkmark$ Albanian GDP: If the Albanian GDP will increase by one unit, while keeping all other factors constant, then Albanian remittances will increase by 0.016516 units.

$\checkmark$ Dummy: Since the coefficient before the dummy variable has been significant, this means that there are structural changes between the two periods before 2000 and after 2000.

$\checkmark$ Unemployment rate: If the unemployment rate will increase by one unit, while keeping all other factors constant, then Albanian remittances will be reduced to 24,033,061 units.

$\checkmark$ Greek population: If the Greek population will increase by one unit, while keeping all other factors constant, then Albanian remittances will grow 207.1191 units. 
$\checkmark$ Albanian population:If the Albanian population will increase by one unit, while keeping all other factors constant, then Albanian remittances will be reduced by 569.0991 units.

\section{Conclusions}

The main purpose of this paper was to point out the effects of remittances in developing countries by focusing specifically on the case of Albania. Following the analysis of the micro and macroeconomic effects, the following conclusions are reached:

First, it can be said that the main difficulty of studying the effects of remittances lies primarily in defining this concept because different researchers give different versions.

- Concerning the microeconomic effects of remittances, it has been concluded that remittances have adverse effects on participation in employment, but in relation to private enterprises and human capital formation studies show that they positively influence. In terms of inequality, most studies support the fact that remittance income increases inequality even though there are studies that show the opposite. What other researchers agree is that remittance income mitigates poverty.

- Concerning macroeconomic effects, it is concluded that remittances are an important item of balance of payments that positively affects economic stability, but whether the issue affects them in economic growth or not, the researchers are divided and can not provide a final answer. But what is to be said is that remittances affect the appreciation of the real exchange rate and the rise in inflation.

In the case of Albania:

- At a macroeconomic level, remittances are an important source of funding to finance the current account. They are the main source of income from abroad and affect a high percentage in mitigating the current account deficit.

- At the micro level, remittances also play an important role in improving the lives of families receiving them. Analyzed on the basis of rural and urban areas, remittances account for a significant percentage of monthly income especially in rural areas. For families with lower levels of income, they are a source of vital income. But they are still used in the mass for consumption and at very low levels for private entrepreneurship and for the creation of human capital.

Secondly, it became the recognition and identification of a link between remittances coming from our neighboring Greece state, which I have taken in the study, and their determining factors. The hypothesis was raised, I found the data and after some attempts I specified that the best model is the dummy independent linear model. It is worth pointing out that the most important and most influential factor of the built model is GDP, because of the country it occupies in the country's economic growth. Relying on probabilities, it results in lower propensity, too close to zero. It remains a matter of further research to identify any other factor that directly or indirectly affects remittances, which come not only from Greece but also from other countries that have a certain share in the remittances of Albanian emigrants, such as Italy, as well as seeing how the crisis has affected those countries in Albanian remittances.

\section{Suggestions}

Migration has a strong positive impact on the development of human resources, the reduction of unemployment and vocational and intellectual training, through the occupations and experience they gain in destination countries.

- Migration brings benefits to a cost-benefit balance only if properly managed for the benefit of the individual, the family, but also the companies of the country of origin and the host country. 
- In general, remittances can contribute to the development of the country (in addition to rising consumption) or directly to productive investment, or by increasing the bank's liquidity level, thus making it possible to obtain loans from entrepreneurs with competitive interests.

- Albanian emigrants in most cases work in sectors that are not preferred by locals, and the vast majority of them have undetermined pay, they serve as a regulatory mechanism in the labor market and contribute to the domestic production of the host country.

- In general, remittances have played an essential role in the Albanian economy and in particular by preventing and alleviating poverty.

- Remittances are an essential component of the current balance of payments account.

- The structure of the use of remittances has changed over the years. If in the first few years the remittances were mainly oriented towards food, clothing, or purchase of household appliances, in the following years the destination was expanded with the improvement of housing conditions (such as residential areas, reconstruction or new constructions) easily visible in areas with high level of migration outside Albania.

- In recent years the inflow of remittances has declined, due to the difficulties created by the negative effects of the economic crisis that have undergone countries of the Eurozone as a whole.

- Migration issues are treated simply as a consequence, but not by finding and recovering in the cause of it. So, first and foremost, state policies have to carry out in-depth studies, what are the causes of migration, which should bring the focus of state policies to discourage escape from the periphery of the country.

- The economic crisis has forced many immigrants to return to Albania, remaining unemployed. Returned migrants may not actively seek information and services from institutions such as Regional Employment Offices. Consequently, awareness campaigns and activities can be used to reach this population that sometimes tends to be invisible.

- Migration of voluntary and involuntary return is still seen as a personal failure and intervention strategies should focus on reducing negativity and promoting a positive climate that encourages acceptance.

-The figures given above, however, are only a part of the total remittances. It is hard to get accurate statistics of real data concerning inflows, as ways of sending remittances, in most cases, are not officially registered. What turns out so far is that the transfer of money through banking or postal institutions is a minimally used procedure by emigrants outside of Albania.

Measures that can be taken are:

Measure 1: Expand and improve the collection of data, practices, research, analysis, policies and procedures related to remittance remittances.

Measure 2: Expansion of banking services in Albania, related to remittance remittances

Measure 3: Promote the Albanian banks and correspondent banks in migrant host countries (particularly in Greece and Italy) to improve services related to remittances from migrants

Measure 4: Strengthening the capacities of the Albanian Institutions Micro Finance (IMF) to provide remittance transfer services from immigrants. 


\section{References}

Acosta, P. (2007). "Entrepreneurship, Labor Markets, and International Remittances: Evidence from El Salvador," in: International Migration, Economic Development and Policy, Ç. Özden and M. Schiff (eds.), World Bank, Washington, D.C.

Adams, R.H. (1991)."The Effects of International Remittances on Poverty, Inequality And Development in Rural Egypt." International Food Policy Research Institute, Washington, D.C.

Adams, R.H., and Page, J. (2003). "International migration, remittances and poverty in developing countries," World Bank Policy Research Working Paper (3179).

Adams, R.H., and Page, J. (2005). "Do international migration and remittances reduce poverty in developing countries?" World Development (33:10), fq 1645-1669.

Ahmed, I.I. (2000) "Remittances and Their Economic Impact on Post-War Somaliland," Disasters (24:4) 2000, pp 380-389.

Amuado-Dorantes, C., and Pozo, S. (2004) "Workers' remittances and the real exchange rate: A paradox of gifts," World Development (32:8), pp 1407-1417.

Banka Botërore, (2012). Migration and Remittances Factbook 2011, second edition.

Banka Botërore. (2012), Migration and Developement Brief 18. http://www.worldbank.org/migration.

Bugamelli, M., and Paterno, F. (2005)."Do Workers' Remittances Reduce the Probability of Current Account Reversals?" World Bank Policy Research Working Paper No: 3766.

Carling, J. (2005). "Migrant remittances and development cooperation". International Peace Research Institute. PRIO Report

Chami, R., Fullenkamp, C., and Jahjah, S. (2003). "Are Immigrant Remittance Flows a Source of Capital for Development?" IMF Working Paper No: 189.

Chami, R., Barajas, A., Cosimano, T., Fullenkamp, C., Gapen, M. and Montiel, P. (2008). "Macroeconomic Consequences of Remittances," IMF Occasional Paper No: 259. Washington DC.

Cox-Edwards, A., and Ureta, M. (2003). "International migration, remittances, and schooling: evidence from El Salvador." Journal of Development Economics pp 429-461.

Daianu, D, Voinea L, and Tolici M. (2001). "Balance of payments financing in Romania: The role of remittances". Romania Center for Economic Policies, Working paper N0.21

Elbadawi I, A and Rocha D, R. (1992). “Determinants of Expatriate Workers' Remittances In North Africa and Europe". World Bank Working Paper No.1038, World Bank, Washington DC

Funkhauser, E. (1992). "Mass emigration, remittances and economic adjust- ment: The case of El Salvador in the 1980s", in G. Borjas and R. Freeman (eds), Migration and the Workforce: Economic Consequences for the United States, University of Chicago Press, Chicago.

Gazeta Shqip. 10 gusht 2014. Artikulli : me pak para nga emigrantet, rritet deficit Gazetadita.al/remitancat-ne-nivelin-me-te-ulet-gjate-3-viteve-te-fundit/

Ghosh, B. (2006). Migrants, Remittances and Development: Myths, Rhetoric and Realities. International Organization for Migration (IOM), Geneva.

INSTAT (2008). Anketa e Buxhetit të Familjes 2006-2007. 
Instituti Agenda. (2011). "Efektet e rënies së remitancave në Shqipëri". Studim I publikuar në korrik 2011.

Kalaj E (2010). "Remittances and Human Capital Investment: Evidence from Albania". World Bank International Conference on Poverty and Social Inclusion in the Western Balkans, Belgium, December 2010.

Kapur, D. (2004) "Remittances: The New Development Mantra?" in: UN Conference on Trade and Development, United Nations, Geneva.

López-Cordova, E. (2005). “Globalization, Migration and Development. The Role of Mexican Migrant Remittances." in Economía. V6, pp.217-256

McKenzie, D., and Rapoport, H. (2004). "Network Effects and the Dynamics of Migration and Inequality: Theory and Evidence from Mexico," BREAD Working Paper No. 063).

Ratha, D. (2003). "Workers' Remittances: An Important and Stable Source of External Development Finance," in: Global Development Finance, World Bank, Washington, D.C.

Ratha, D. (2006). "Trends, Determinants and Macroeceonomic Effects of Remittancs," in: Global Economics Prospects 2006: Economic Implications of Remittances and Migration, World Bank, Washington, D.C.

Rapoport, H., and Docquier, F. (2005). “The Economics of Migrants' Remittances," IZA discussion papers, Institute for the Study of Labor (IZA).

Rapoport H and Docquier F (2006). "The economics of Migrants' Remittances": 1135-1199 in S.C. Kolm and J.M. Ythier (eds.) Handbook of the Economics of Giving, Altruism and Reciprocity: Volume 2, North-Holland: Amsterdam.

Rodriguez, E.R. (1998). "International migration and income distribution in the Philippines," Economic Development and Cultural Change, 46: 2, p 329.

Sander, C. (2003). "Migrant Remittances to Developing Countries - A Scoping Study: Overview and Introduction to Issues for Pro-Poor Financial Services."

Taylor, J.E., Mora, J., Adams, R., and Lopez-Feldman, A. (2005). "Remittances, Inequality and Poverty: Evidence from Rural Mexico," in: American Agricultural Economics Association Annual Meeting, Providence, Rhode Island.

Woodruff, C., and Zenteno, R. (2001). "Remittances and Micro-enterprises in Mexico" Working paper, UCSD.

World Bank (2011). Migration and Remittances Factbook 2011. 23 prill 2012.

Yang, D. (2004). "International Migration, Human Capital, and Entrepreneurship: Evidence from Philippine Migrants' Exchange Rate Shocks," Ford School for Public Policy Working Paper).

Zolberg A., (1989). The next waves: migration theory for changing world, International Migration Reviews. 


\section{Appendices}

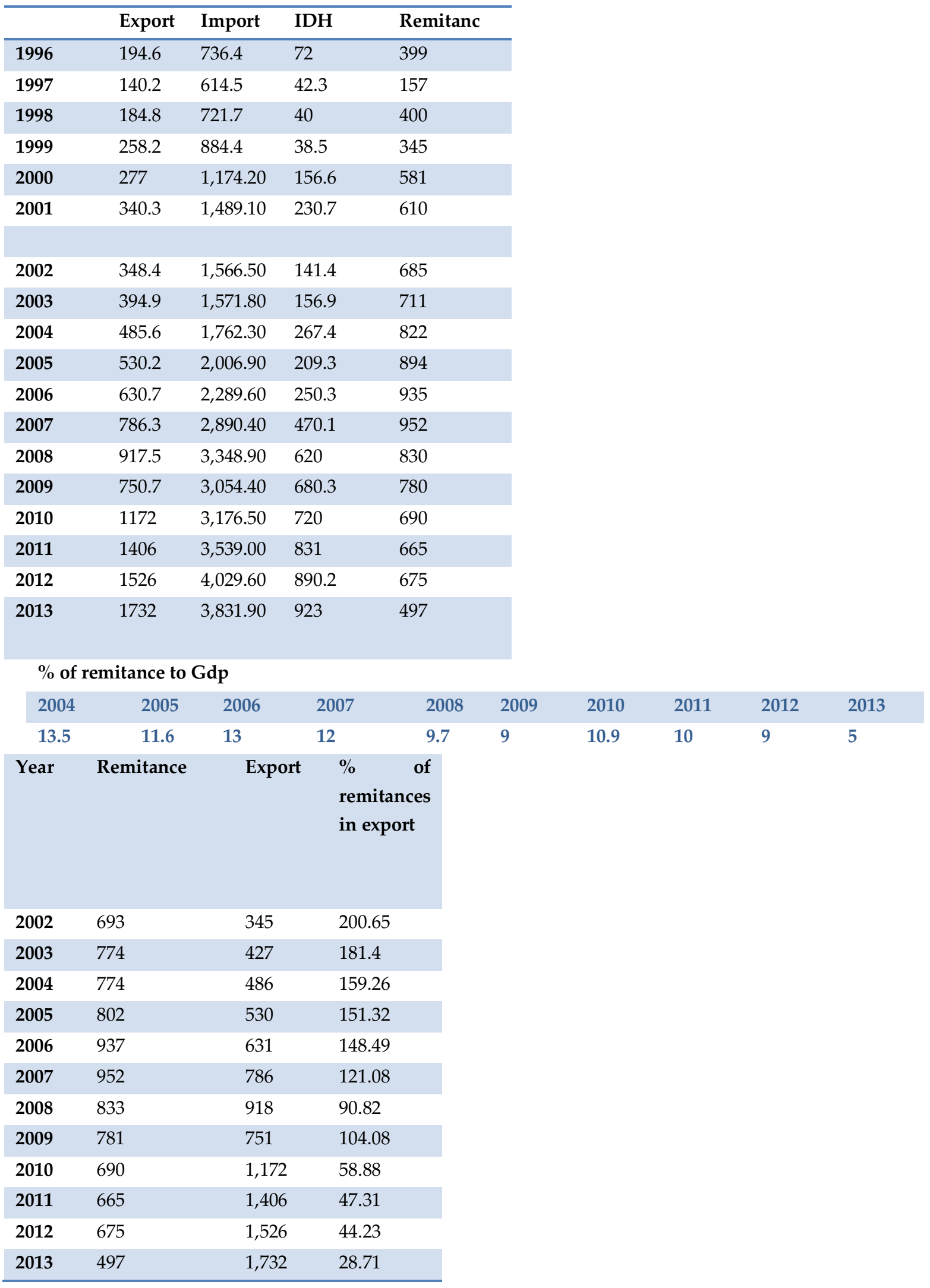

